\title{
Analysis of autosomal dominant genes impacted by copy number loss in 24,844 fetuses without structural abnormalities
}

\author{
Lin Chen ${ }^{1,2}$, Li Wang ${ }^{1,2}$, Daishu Yin ${ }^{1,2}$, Feng Tang ${ }^{1,2}$, Yang Zeng ${ }^{1,2}$, Hongmei Zhu ${ }^{1,2}$ and Jing Wang ${ }^{1,2^{*}}$
}

\begin{abstract}
Background: The broad application of high-resolution chromosome detection technology in prenatal diagnosis has identified copy number loss (CNL) involving autosomal dominant (AD) genes in certain fetuses. Exon sequencing of fetuses exhibiting structural anomalies yields diagnostic information in up to $20 \%$ of cases. However, there is currently no relevant literature about the genetic origin and pregnancy outcome of CNL involving AD genes in fetuses without structural abnormalities.

Results: This was a prospective study involving pregnant women who underwent amniocentesis for fetal copy number variation sequencing (CNVseq). Detection of parent-of-origin was suggested in cases of samples with CNL involving AD genes and the pregnancy outcome was monitored. Amniotic fluid samples from 24,844 fetuses without structural abnormalities were successfully tested via CNVseq. The results showed that 134 fetuses (0.5\%) had small $\mathrm{CNL}(<10 \mathrm{Mb})$ containing AD genes, after excluding microdeletion and microduplication syndrome and polymorphisms. By monitoring the pregnancy outcomes of the 134 fetuses, we found that 104 (77.6\%) were good, 13 (9.7\%) were adverse, and 17 (12.7\%) pregnant women voluntarily chose to terminate pregnancy. Of the 13 fetuses with adverse pregnancy outcomes, only 2 fetuses had phenotypes consistent with those of diseases caused by AD genes involved in CNL.
\end{abstract}

Conclusions: The overall prognosis for fetuses without family history or structural abnormalities but with small CNL containing AD genes detected during pregnancy is good. The genetic origin, overlap status of established haploinsufficient gene and/or region, size of the CNL, and genetic mode may affect the pathogenicity of the CNL.

Keywords: Fetus, CNV: Copy number variation, Invasive prenatal diagnosis, CNL: Copy number loss, AD: Autosomal dominant, Gene, Prognosis

\section{Background}

Prenatal ultrasound is an established screening tool in obstetrics that provides increasingly high resolution to identify fetal structural abnormalities in approximately $5 \%$ of pregnancies [1]. The identification of chromosomal or genetic abnormalities is an important factor affecting

\footnotetext{
*Correspondence: hhwj_123@163.com

1 Department of Obstetrics and Gynecology, West China Second

University Hospital of Sichuan University, Chengdu 610041, China

Full list of author information is available at the end of the article
}

fetal prognosis. Karyotyping and chromosomal microarray analysis (CMA) reveal that approximately $40 \%$ of these fetuses have genomic copy number variations (CNVs). However, close to $60 \%$ fail to receive a genomic diagnosis with which to inform prognosis and initiate genetic counseling [2]. In recent years, the implementation of prenatal exon sequencing (ES) in clinical practice to evaluate fetuses with structural anomalies has vastly improved the delineation of prognosis, providing clinical utility for a deeper understanding of the pathogenesis of prenatal genetic disorders. Prenatal ES in fetal structural 
anomalies yields diagnostic information in up to $20 \%$ of cases [3].

In some prenatal diagnostic centers, up to $74.8-96.8 \%$ of the fetuses undergoing invasive prenatal diagnosis did not exhibit structural abnormalities before amniocentesis [4-6]. Other indications for prenatal diagnosis include advanced maternal age, increased risk of a screening test, ultrasound soft markers, and maternal request; the main purpose is to detect genomic $\mathrm{CNV}$, including aneuploidy and unbalanced chromosomal rearrangements. At present, high-resolution chromosome detection techniques, such as CMA and copy number variation sequencing (CNVseq), are widely used in fetal chromosome detection [7-12]. Compared with conventional karyotyping, CMA and CNVseq have an additional detection rate of $1-6 \%$ for clinically significant CNVs $[6,7,13,14]$ and also identify copy number loss (CNL) involving autosomal dominant (AD) genes.

For fetuses without ultrasound structural abnormalities, if high-resolution chromosome detection techniques indicate that there are CNL including AD genes in fetuses during pregnancy, what are their genetic origins and pregnancy outcomes? At present, such literature is lacking. This study sought to analyze the above contents to provide useful information for prenatal genetic counseling of mothers carrying fetuses with CNL.

\section{Results}

From February 2017 to June 2020, amniotic fluid samples from 24844 fetuses without structural abnormalities were successfully analyzed via CNVseq. The results showed that 134 fetuses (0.5\%) had CNL involving AD genes $(<10 \mathrm{Mb})$ after excluding microdeletion and microduplication syndrome (MMS) and polymorphisms; the average size of the CNL was $1.11 \mathrm{Mb}, \mathrm{CNL}$ involved a total of 202 AD genes, covering 128 different AD genes. Among the 134 samples, 37 carried two or more $\mathrm{AD}$ genes and one contained seven different $\mathrm{AD}$ genes. Among the 128 different genes, 23 (18.0\%) were detected in multiple samples; NIPA1 was the most common gene (25 samples), followed by CTNNA3 (10 samples). According to the genomic location of genes (Fig. 1), these 128 genes were distributed across nearly all autosomes, with the highest number found on chromosome 15 (27 genes), followed by chromosomes 1 and 10 (23 genes, respectively); no CNL involving $\mathrm{AD}$ genes was found on chromosomes 14 and 19. The genomic positions, occurrences, genetic origins, and genetic modes of all 128 genes are summarized in the Supplementary Table.

Our follow-up on the pregnancy outcomes of the 134 fetuses found that $104(77.6 \%)$ had good outcomes, 13 (9.7\%) had adverse outcomes, and 17 (12.7\%) pregnant women voluntarily chose termination of pregnancy
(TOP). Details of the fetuses with adverse pregnancy outcomes are summarized in Table 1. CNL of the 134 samples were divided into inherited, de novo, and unknown according to their genetic origins. Then, the CNL overlap of established haploinsufficient (HI) gene and/or region (abbreviated as overlap of $\mathrm{HI}$ ), average size of $\mathrm{CNL}$, and outcome of pregnancy in each group were analyzed. The results showed that the number of samples that overlap of $\mathrm{HI}$ was the greatest, and the average size of CNL was the largest in the de novo group. Compared with the de novo group, the proportion of normal infants in the inherited group was higher (Pearson's Chi-squared test, $P=0.000$ ); the proportion of abnormal pregnancy outcomes was lower, but the difference was not statistically significant (Yates' continuity correction of the Chisquared test, $P>0.05$ ). In the three groups, the rate of voluntary TOP in the de novo group was much higher than that in the other two groups (Yates' continuity correction of the Chi-squared test, $P=0.000$ ). These details are presented in Table 2.

Based on content in the Online Mendelian Inheritance in $\mathrm{Man}^{\circledR}$ database (OMIM, https://omim.org/), we analyzed information regarding gene pathogenicity. Among the 128 different genes, 65 (50.8\%) exhibited multiple genetic modes. A total of $202 \mathrm{AD}$ genes were detected in 134 samples, which were divided into inherited, de novo, and unknown origin groups. Our results showed that, in the de novo group, the proportion of genes with multiple genetic modes was higher than that in the inherited group. The specific information is listed in Table 3.

CNL were divided into $<1 \mathrm{Mb}, 1-3 \mathrm{Mb}$, and $>3 \mathrm{Mb}$ groups according to fragment size. The results showed that the number of samples with $\mathrm{CNL}<1 \mathrm{Mb}$ accounted for the largest proportion (73.1\%). The smaller the fragment, higher the proportion of normal pregnancy outcomes and lower the proportion of abnormal pregnancy outcomes, but there was no significant difference (Fisher's exact test, Yates' continuity correction of the Chisquared test and Pearson's Chi-squared test, $\mathrm{P}>0.05$ ). The relevant information is shown in Table 4.

\section{Discussion}

In the nearly 60 years since prenatal diagnosis of genetic diseases was first proposed, the field has made great progress. While invasive fetal sampling technology has improved, the technological progress of cytogenetics and molecular biology has expanded the scope of genetic disease diagnosis even further. Presently, chorionic villus sampling and amniocentesis can be used to diagnose the majority of diseases with known genetic causes; moreover, the genomes and exomes of abnormal fetuses can be sequenced to help identify potential genetic vulnerabilities [15-19]. 


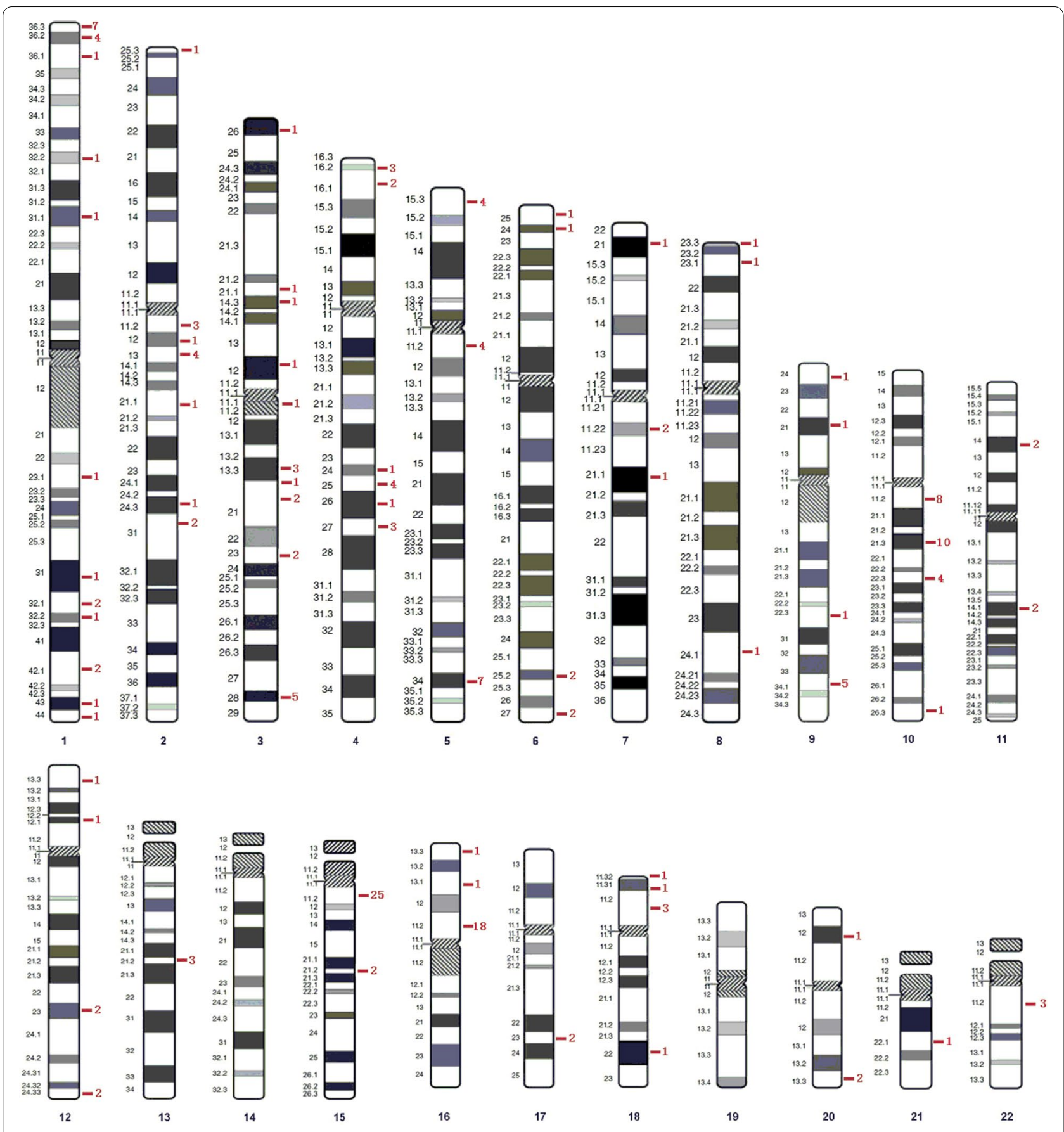

Fig. 1 The genomic location of genes. The red Arabic numerals represent the number of genes located in the genome.

Theoretically, full gene, single-exon, or multi-exon deletion is often assumed to disrupt gene function by causing the complete absence of the gene product due to lack of transcription or nonsense-mediated decay of an altered transcript as identified by very strong evidence of pathogenicity in the ACMG/AMP guidelines [20]. However, our follow-up on the pregnancy outcomes of the
134 fetuses in this study found that 13 (9.7\%) had abnormal phenotypes and only 2 had abnormal phenotypes consistent with the phenotypes of diseases caused by AD genes. Most of the women (77.6\%) had good pregnancy outcomes, possibly because CNL in these subjects did not affect the functional region of the $\mathrm{AD}$ gene, partial exon deletion did not affect the protein integrity, loss of 
Table 1 CNL involving AD genes: Information on 13 fetuses with adverse pregnancy outcomes

\begin{tabular}{|c|c|c|c|c|c|c|c|}
\hline Case number & $\begin{array}{l}\text { Indications of } \\
\text { amniocentesis }\end{array}$ & Location & Size (Mb) & Gene & $\begin{array}{l}\text { Phenotype and } \\
\text { Inheritance }\end{array}$ & Origin & $\begin{array}{l}\text { Pregnancy } \\
\text { outcomes }\end{array}$ \\
\hline A1 & ultrasound soft markers & $6 p 25.3 p 25.2$ & 1.72 & FOXC1 & $\begin{array}{l}\text { Anterior segment dysgene- } \\
\text { sis 3, multiple subtypes AD; } \\
\text { Axenfeld-Rieger syndrome, } \\
\text { type } 3 \text { AD }\end{array}$ & De novo & $\begin{array}{l}\text { Facial abnormalities, Poste- } \\
\text { rior fossa extraaxial cyst }\end{array}$ \\
\hline $\mathrm{A} 2$ & advanced maternal age & $6 q 27$ & 1.22 & ERMARD & $\begin{array}{l}\text { Periventricular nodular } \\
\text { heterotopia } 6 \mathrm{AD}\end{array}$ & Maternal & $\begin{array}{l}\text { Ventricular septal defect } \\
7 \mathrm{~mm}\end{array}$ \\
\hline A3 & $\begin{array}{l}\text { increased risk of a screening } \\
\text { test }\end{array}$ & $11 q 14.1 q 14.2$ & 8.26 & $\begin{array}{l}\text { ALG8; } \\
\text { TENM4 }\end{array}$ & $\begin{array}{l}\text { Congenital disorder of } \\
\text { glycosylation, type Ih AR; } \\
\text { Polycystic liver disease } 3 \\
\text { with or without kidney } \\
\text { cysts AD; } \\
\text { Essential tremor, hereditary, } \\
5 \text { AD }\end{array}$ & Unknown & Multiple malformations \\
\hline A4 & ultrasound soft markers & $10 q 21.3$ & 0.38 & CTNNA3 & $\begin{array}{l}\text { Arrhythmogenic right ven- } \\
\text { tricular dysplasia, familial, } \\
13 \mathrm{AD}\end{array}$ & Unknown & $\begin{array}{l}\text { Duodenal stenosis and } \\
\text { atresia }\end{array}$ \\
\hline A5 & $\begin{array}{l}\text { increased risk of a screening } \\
\text { test }\end{array}$ & $4 q 25$ & 0.22 & SGMS2 & $\begin{array}{l}\text { Calvarial doughnut lesions } \\
\text { with bone fragility with or } \\
\text { without spondylometaphy- } \\
\text { seal dysplasia AD }\end{array}$ & Paternal & Hypospadias \\
\hline A6 & advanced maternal age & $4 q 24$ & 0.62 & РPР3СA & $\begin{array}{l}\text { Arthrogryposis, cleft } \\
\text { palate, craniosynostosis, } \\
\text { and impaired intellectual } \\
\text { development AD; Devel- } \\
\text { opmental and epileptic } \\
\text { encephalopathy } 91 \text { AD }\end{array}$ & Unknown & Hydronephrosis \\
\hline A7 & $\begin{array}{l}\text { increased risk of a screening } \\
\text { test }\end{array}$ & $18 q 22.3 q 23$ & 4.18 & TSHZ1 & Aural atresia, congenital AD & De novo & Developmental retardation \\
\hline A8 & advanced maternal age & $11 \mathrm{p} 15.1 \mathrm{p} 14.3$ & 3.26 & ANO5 & $\begin{array}{l}\text { Gnathodiaphyseal dysplasia } \\
\text { AD; Miyoshi muscular } \\
\text { dystrophy } 3 \text { AR; Muscular } \\
\text { dystrophy, limb-girdle, } \\
\text { autosomal recessive } 12 \text { AR }\end{array}$ & De novo & Brain glioma \\
\hline A9 & $\begin{array}{l}\text { increased risk of a screening } \\
\text { test }\end{array}$ & $11 p 14.3$ & 0.16 & ANO5 & $\begin{array}{l}\text { Gnathodiaphyseal dysplasia } \\
\text { AD; Miyoshi muscular } \\
\text { dystrophy } 3 \text { AR; Muscular } \\
\text { dystrophy, limb-girdle, } \\
\text { autosomal recessive } 12 \text { AR }\end{array}$ & Unknown & Multiple malformations \\
\hline A10 & advanced maternal age & $5 q 11.2$ & 0.22 & PDE4D & $\begin{array}{l}\text { Acrodysostosis 2, with or } \\
\text { without hormone resist- } \\
\text { ance AD }\end{array}$ & Unknown & Deaf \\
\hline A11 & ultrasound soft markers & $3 p 26.1$ & 0.34 & ITPRI & $\begin{array}{l}\text { Gillespie syndrome AD, AR; } \\
\text { Spinocerebellar ataxia } 15 \\
\text { AD; } \\
\text { Spinocerebellar ataxia } 29 \text {, } \\
\text { congenital nonprogres- } \\
\text { sive AD }\end{array}$ & Paternal & Short limbs \\
\hline $\mathrm{A} 12$ & $\begin{array}{l}\text { increased risk of a screening } \\
\text { test }\end{array}$ & $15 q 11.2$ & 0.32 & NIPAI & $\begin{array}{l}\text { Spastic paraplegia 6, auto- } \\
\text { somal dominant AD }\end{array}$ & Paternal & Spontaneous abortion \\
\hline A13 & $\begin{array}{l}\text { increased risk of a screening } \\
\text { test }\end{array}$ & $20 q 13.33$ & 0.14 & $\begin{array}{l}\text { CHRNA4; } \\
\text { KCNQ2 }\end{array}$ & $\begin{array}{l}\text { \{Nicotine addiction, suscep- } \\
\text { tibility to\}; } \\
\text { Epilepsy, nocturnal frontal } \\
\text { lobe, } 1 \text { AD; } \\
\text { Developmental and epilep- } \\
\text { tic encephalopathy } 7 \text { AD; } \\
\text { Myokymia AD; } \\
\text { Seizures, benign neonatal, } \\
1 \text { AD }\end{array}$ & Unknown & Epilepsy \\
\hline
\end{tabular}


Table 2 CNV information and pregnancy outcome of CNVs grouped by parent-of-origin

\begin{tabular}{|c|c|c|c|c|c|c|}
\hline \multirow[t]{2}{*}{ Group } & \multirow{2}{*}{$\begin{array}{l}\text { Number of } \\
\text { samples, } \boldsymbol{n}(\%)\end{array}$} & \multirow{2}{*}{$\begin{array}{l}\text { Overlap of } \\
\mathrm{HI}, n(\%)\end{array}$} & \multirow{2}{*}{$\begin{array}{l}\text { Average size of } \\
\text { CNV(Mb) }\end{array}$} & \multicolumn{3}{|c|}{ Outcome of pregnancy, $n(\%)$} \\
\hline & & & & Normal infants & $\begin{array}{l}\text { Abnormal } \\
\text { pregnancy } \\
\text { outcomes }\end{array}$ & Voluntary TOP \\
\hline Detection of parent-of-origin & $\begin{array}{l}82 \\
(61.2 \%)\end{array}$ & $\begin{array}{l}25 \\
(30.5 \%)\end{array}$ & 1.07 & $\begin{array}{l}62 \\
(75.6 \%)\end{array}$ & $\begin{array}{l}7 \\
(8.5 \%)\end{array}$ & $\begin{array}{l}13 \\
(15.9 \%)\end{array}$ \\
\hline Inherited & $\begin{array}{l}60 \\
(73.2 \%)\end{array}$ & $\begin{array}{l}15 \\
(25.0 \%)\end{array}$ & 0.81 & $\begin{array}{l}55 \\
(91.7 \%)\end{array}$ & $\begin{array}{l}4 \\
(6.7 \%)\end{array}$ & $\begin{array}{l}1 \\
(1.7 \%)\end{array}$ \\
\hline De novo & $\begin{array}{l}22 \\
(26.8 \%)\end{array}$ & $\begin{array}{l}10 \\
(45.5 \%)\end{array}$ & 1.77 & $\begin{array}{l}7 \\
(31.8 \%)\end{array}$ & $\begin{array}{l}3 \\
(13.6 \%)\end{array}$ & $\begin{array}{l}12 \\
(54.5 \%)\end{array}$ \\
\hline Unknown origin & $\begin{array}{l}52 \\
(38.8 \%)\end{array}$ & $\begin{array}{l}16 \\
(30.8 \%)\end{array}$ & 1.18 & $\begin{array}{l}42 \\
(80.8 \%)\end{array}$ & $\begin{array}{l}6 \\
(11.5 \%)\end{array}$ & $\begin{array}{l}4 \\
(7.7 \%)\end{array}$ \\
\hline Total & $\begin{array}{l}134 \\
(100.0 \%)\end{array}$ & $\begin{array}{l}41 \\
(30.6 \%)\end{array}$ & 1.11 & $\begin{array}{l}104 \\
(77.6 \%)\end{array}$ & $\begin{array}{l}13 \\
(9.7 \%)\end{array}$ & $\begin{array}{l}17 \\
(12.7 \%)\end{array}$ \\
\hline
\end{tabular}

CNV, copynumbervariation; $\mathrm{Hl}$, Haploinsufficiency; TOP, termination of pregnancy

Table 3 Information about gene pathogenicity

\begin{tabular}{|c|c|c|c|c|c|}
\hline Group & $\begin{array}{l}\text { One patient or family } \\
\text { reported }\end{array}$ & Susceptibility & Somatic & ARorDD & Only AD \\
\hline $\begin{array}{l}\text { different genes } \\
(n=128)\end{array}$ & $\begin{array}{l}14 \\
(10.9 \%)\end{array}$ & $\begin{array}{l}18 \\
(14.1 \%)\end{array}$ & $\begin{array}{l}6 \\
(4.7 \%)\end{array}$ & $\begin{array}{l}40 \\
(31.3 \%)\end{array}$ & $\begin{array}{l}63 \\
(49.2 \%)\end{array}$ \\
\hline $\begin{array}{l}\text { Total number of genes } \\
(n=202)\end{array}$ & $\begin{array}{l}16 \\
(7.9 \%)\end{array}$ & $\begin{array}{l}22 \\
(10.9 \%)\end{array}$ & $\begin{array}{l}8 \\
(4.0 \%)\end{array}$ & $\begin{array}{l}51 \\
(25.2 \%)\end{array}$ & $\begin{array}{l}122 \\
(60.4 \%)\end{array}$ \\
\hline $\begin{array}{l}\text { Inherited } \\
(n=81)\end{array}$ & $\begin{array}{l}10 \\
(12.3 \%)\end{array}$ & $\begin{array}{l}9 \\
(11.1 \%)\end{array}$ & $\begin{array}{l}1 \\
(1.2 \%)\end{array}$ & $\begin{array}{l}19 \\
(23.5 \%)\end{array}$ & $\begin{array}{l}49 \\
(60.5 \%)\end{array}$ \\
\hline $\begin{array}{l}\text { De novo } \\
(n=42)\end{array}$ & $\begin{array}{l}2 \\
(4.8 \%)\end{array}$ & $\begin{array}{l}6 \\
(14.3 \%)\end{array}$ & $\begin{array}{l}4 \\
(9.5 \%)\end{array}$ & $\begin{array}{l}12 \\
(28.6 \%)\end{array}$ & $\begin{array}{l}22 \\
(52.4 \%)\end{array}$ \\
\hline $\begin{array}{l}\text { Unknown origin } \\
(n=79)\end{array}$ & $\begin{array}{l}4 \\
(5.1 \%)\end{array}$ & $\begin{array}{l}7 \\
(8.9 \%)\end{array}$ & $\begin{array}{l}3 \\
(3.8 \%)\end{array}$ & $\begin{array}{l}20 \\
(25.3 \%)\end{array}$ & $\begin{array}{l}51 \\
(64.6 \%)\end{array}$ \\
\hline
\end{tabular}

$A R$, Autosomal recessive, $D D$, Digenic dominant, $A D$, Autosomal dominant

Table 4 Information and pregnancy outcome of different sizes of CNVs

\begin{tabular}{|c|c|c|c|c|c|c|}
\hline \multirow[t]{2}{*}{ Size of CNV } & \multirow{2}{*}{$\begin{array}{l}\text { Number of } \\
\text { samples, } \mathbf{n}(\%)\end{array}$} & \multirow{2}{*}{$\begin{array}{l}\text { Average size of } \\
\text { CNV (Mb) }\end{array}$} & \multirow[t]{2}{*}{ Overlap of $\mathrm{HI}, \mathbf{n}(\%)$} & \multicolumn{3}{|c|}{ Outcome of pregnancy, $n(\%)$} \\
\hline & & & & Normal infants & $\begin{array}{l}\text { Abnormal } \\
\text { pregnancy } \\
\text { outcomes }\end{array}$ & Voluntary TOP \\
\hline$<1 \mathrm{Mb}$ & $\begin{array}{l}98 \\
(73.1 \%)\end{array}$ & 0.39 & $37(37.8 \%)$ & $82(83.7 \%)$ & $8(8.2 \%)$ & $8(8.2 \%)$ \\
\hline $1-3 \mathrm{Mb}$ & $\begin{array}{l}20 \\
(14.9 \%)\end{array}$ & 2.01 & $2(10.0 \%)$ & $13(65.0 \%)$ & $2(10.0 \%)$ & $5(25.0 \%)$ \\
\hline$>3 \mathrm{Mb}$ & $\begin{array}{l}16 \\
(11.9 \%)\end{array}$ & 4.46 & $2(12.5 \%)$ & $9(56.3 \%)$ & $3(18.8 \%)$ & $4(25.0 \%)$ \\
\hline Total & $\begin{array}{l}134 \\
(100.0 \%)\end{array}$ & 1.11 & $41(30.6 \%)$ & $104(77.6 \%)$ & $13(9.7 \%)$ & $17(12.7 \%)$ \\
\hline
\end{tabular}

CNV, copynumbervariation; $H I$, Haploinsufficiency; TOP, termination of pregnancy

function was not the pathogenic mechanism of the disease, loss of function was at the 3' terminal, or the gene had multiple transcripts [20-23]. In addition, certain autosomal dominant genetic diseases have incomplete penetrance, late onset age, and variable expressivity [24-26].

The results of this study showed that in the de novo group, the proportion of samples that overlap of HI was 
the highest, average size of the CNL was the biggest, and proportion of fetal adverse pregnancy outcome was the highest. At the same time, larger the CNL fragment, the higher the proportion of adverse pregnancy outcomes. Whether CNL overlaps the HI gene or region, the number of protein coding genes involved in genomic variation and genetic origin are important components of the pathogenicity classification of CNV [20,27]. Generally, the larger the CNL fragment, the more protein coding genes involved. Therefore, if the CNL overlaps $\mathrm{HI}$ and the CNL fragment is large and de novo, the pathogenicity classification of CNL tends to be pathogenic or likely pathogenic. According to information provided in the OMIM database, in addition to AD inheritance, some genes may have other ways of causing diseases, such as disease susceptibility, somatic variation, autosomal recessive inheritance, or digenic inheritance. Some genes have been reported in only one patient or family, requiring further confirmation of the correlation with disease [28, $29]$. The results of this study showed that, in the de novo group, the proportion of genes with multiple genetic modes was higher than that in the inherited group. In brief, the genetic origin of variation, overlap of $\mathrm{HI}$, size of $\mathrm{CNL}$, and genetic mode may affect the pathogenicity of CNL.

At present, neither CNVseq nor CMA technology can determine the accurate breakpoint location of CNVs [30]. Among 134 fetuses with CNL, 36 samples had CNL only partially covers an $\mathrm{AD}$ gene, we cannot identify the specific region of the $\mathrm{AD}$ gene covered by the CNL and whether it involves a coding/functional region; consequently, we cannot know whether this variation causes gene dysfunction and disease. However, if each sample is tested via other methods to determine the specific deletion region of the $\mathrm{AD}$ gene and the effect of gene function, this will undoubtedly increase the cost of detection and prolong the time required to obtain the report, leading to even greater anxiety in pregnant women. In this study, the biological parents of 82 fetuses were compared: among them, 60 fetuses (73.2\%) inherited CNL from a parent with normal phenotype. Through follow-up, we determined that only 4 fetuses (6.7\%) had abnormal pregnancy outcomes: A2, A5, A11, and A12. However, their phenotypes were not consistent with those of patients diagnosed with diseases caused by the $\mathrm{AD}$ genes involved in CNL. The CNL of 22 fetuses (26.8\%) were de novo and 3 fetuses (13.6\%) had adverse outcomes (A1, A7, and A8), with only the phenotype of A1 consistent with the $\mathrm{AD}$ gene involved in CNL. The genetic origin of CNL in 52 samples was unclear; 6 cases $(11.5 \%)$ had adverse outcomes, with only the phenotype of one fetus (A13) associated with the disease caused by the AD gene involved in CNL. From the data shown in Table 2, we can see that compared with the unknown origin group, if the fetal $\mathrm{CNL}$ is inherited from the father or mother with normal phenotype, the proportion of normal pregnancy outcomes is higher and the proportion of voluntary TOP is lower. However, if the fetal CNL is de novo, the proportion of voluntary TOP is very high $(12 / 22,54.5 \%)$; we cannot know whether these fetuses would have had abnormal phenotypes, which may lead to the termination of many healthy fetuses. Therefore, in order to provide more reasonable medical advice-while saving time and lowering cost-it is recommended that the genetic origin of the CNL be confirmed to help evaluate its pathogenicity. If CNL is genetic in origin, an analysis of the pathogenicity of the $\mathrm{AD}$ gene by combining the phenotypes of parents and family members is warranted. In this study, the proportion of normal pregnancy outcomes in the inherited group was $91.7 \%$ (55/60). If the CNL is de novo, it is suggested that other methods be used to confirm the effect of the CNL on the function of the AD gene to help determine its pathogenicity, so as to provide more data-driven medical advice to pregnant women and their families.

\section{Conclusions}

The overall prognosis for fetuses without family history or structural abnormalities but with small CNL containing $\mathrm{AD}$ genes $(<10 \mathrm{Mb})$ detected during pregnancy, after excluding MMS and polymorphism, is good. Protocols that combine the CNL data of parents with the results of $\mathrm{AD}$ gene function tests are critical to inform medical consultation and decision rules.

\section{Methods}

\section{Study patients}

This study involved pregnant women who underwent amniocentesis for fetal CNVseq during their second or third trimester due to reasons, such as advanced maternal age, increased risk of a screening test, ultrasound soft markers, or maternal request at West China Second University Hospital of Sichuan University from February 2017 to June 2020. Fetuses with structural abnormalities, based on the ultrasonogram before amniocentesis and family history of a genetic condition, were excluded.

\section{Amniotic fluid sample collection and DNA extraction}

Based on routine collection procedures, $20 \mathrm{~mL}$ amniotic fluid was extracted and separated into 4 sterile centrifuge tubes containing $4 \mathrm{~mL}, 4 \mathrm{~mL}, 6 \mathrm{~mL}$, and $6 \mathrm{~mL}$, respectively. CNVseq was performed using the $6-\mathrm{mL}$ amniotic fluid samples and quantitative fluorescence PCR (QFPCR) was performed using one of the 4-mL amniotic fluid samples. The other two tubes of amniotic fluid were stored in a $2-8{ }^{\circ} \mathrm{C}$ refrigerator. According to the manufacturer's 
Pregnant women with high risk factors of fetal chromosomal abnormalities or maternal request, fetuses with structural abnormalities by ultrasonogram before amniocentesis and family history of a genetic condition were excluded.

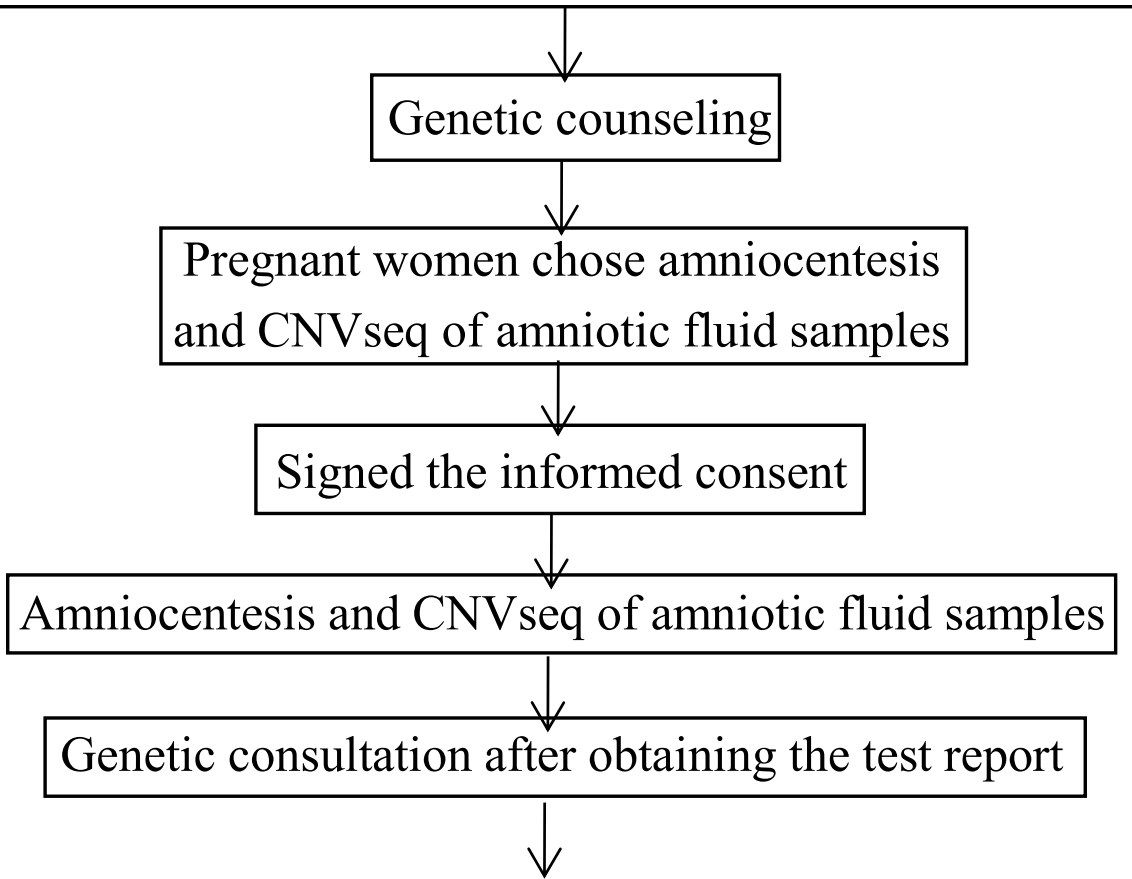

When copy number loss including AD gene was identified in the amniotic fluid sample, we recommended that the biological parents of the fetus underwent CNVseq to determine the origin of the CNV of the fetus.

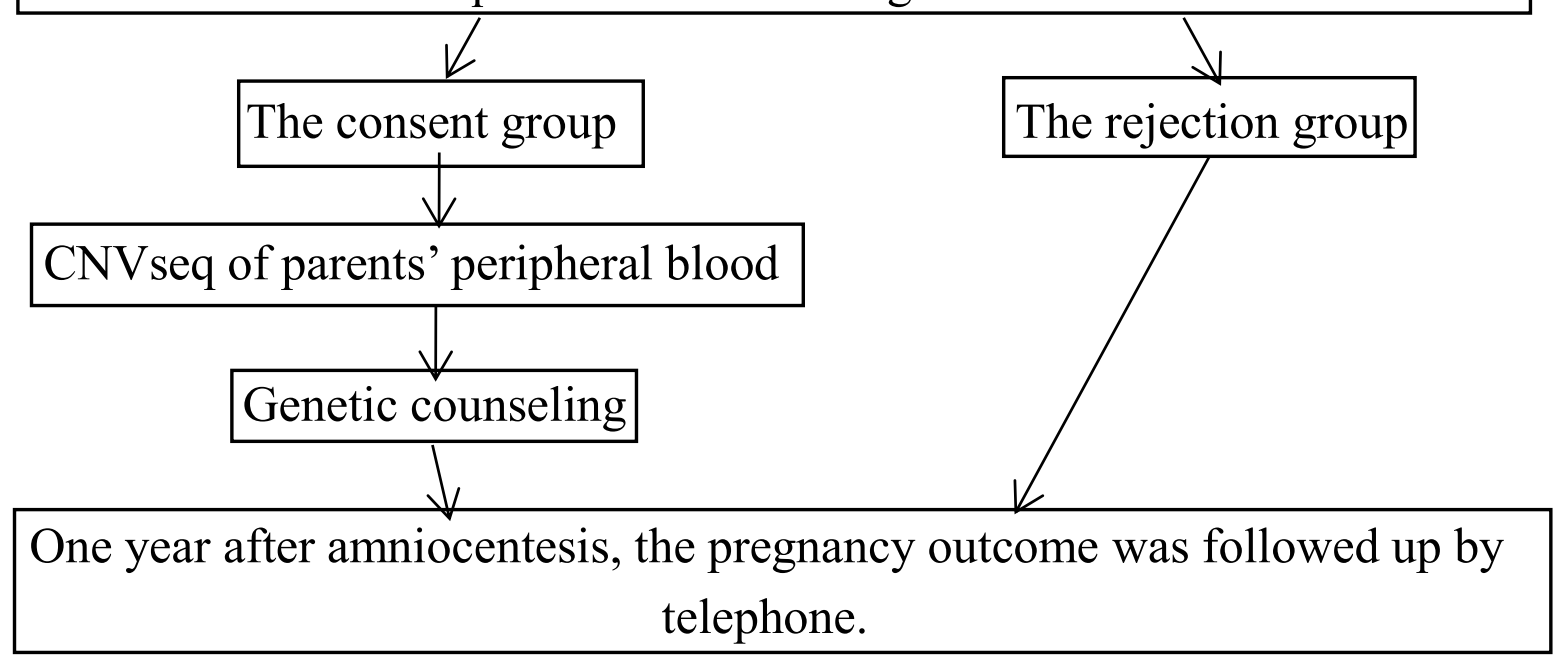

Fig. 2 The flowchart of the study 
instructions, DNA was extracted from amniotic fluid samples using a DNeasy Blood and Tissue Kit (Qiagen, Hilden, Germany). QF-PCR was performed using 21 trisomy/sex chromosome/polyploidy and 18 trisomy/13 trisomy/polyploidy detection kits (DaAn Gene, Guangzhou, China). When QF-PCR results indicated the presence of maternal cells in the samples, CNVseq and QF-PCR were repeated on the spare samples after cell culture.

\section{CNVseq}

DNA libraries were prepared using a Chromosome CNV Detection kit (Berry Genomics, Beijing, China) and subsequently sequenced on the Illumina NextSeq500 sequencing platform using a NextSeq500 High Output kit (Illumina, San Diego, CA, USA) according to the manufacturer's instructions. We compared the reads obtained by next generation sequencing with the GRCh37 reference genome and performed bioinformatics analysis to obtain the genomic copy number information of the samples as described previously [14]. In this study, the pathogenicity of CNVs > $100 \mathrm{~kb}$ was analyzed. The clinical significance of the CNVs was interpreted according to the technical standards for the interpretation and reporting of constitutional CNVs established by joint consensus of the American College of Medical Genetics and Genomics (ACMG) and the Clinical Genome Resource (ClinGen) [31]. After excluding MMS and polymorphisms ( $>1 \%$ in the general population), $\mathrm{CNL}$ (the copy number is 1 ) involving $\mathrm{AD}$ genes with fragment sizes $<10 \mathrm{Mb}$ were included in the present study. CNVs were confirmed using array-based comparative genomic hybridization (aCGH) or a repeat of CNVseq. aCGH was performed using a CGX v2 Oligo aCGH Kit (Agilent Technologies, Santa Clara, CA, USA). The microarray was scanned using the Agilent SureScan Microarray Scanner (Agilent). Data were extracted using the Agilent CytoGenomics software (Agilent) and analyzed using the Genoglyphix Analysis software (PerkinElmer, Waltham, MA, USA).

\section{Detection of parent-of-origin}

When $\mathrm{CNL}$ involving $\mathrm{AD}$ genes was identified in the amniotic fluid sample, we recommended that the biological parents of the fetus undergo CNVseq to determine the origin of the fetal CNL; $2 \mathrm{~mL}$ of peripheral blood was collected from each parent and anticoagulated with EDTA. DNA extraction and CNVseq methods were performed as described for the amniotic fluid samples.

\section{Follow-up of pregnancy outcome}

One year after amniocentesis, the researchers contacted the mother or father of the fetus for follow-up. The information discussed during the inquiry included fetal ultrasound results; pregnancy complications; pregnancy loss; TOP and the causes; date and mode of delivery; weight and length of the newborn; the Apgar score; physical appearance of the newborn (i.e., normal/abnormal); feeding conditions after birth; and examination results of pediatric outpatient services. The flowchart of the study is shown in Fig. 2.

\begin{abstract}
Abbreviations
CNL: Copy number loss; AD: Autosomal dominant; CNVseq: Copy number variation sequencing; CMA: Chromosomal microarray analysis; CNVs: Copy number variations; QF-PCR: Quantitative fluorescence PCR; ACMG: American College of Medical Genetics and Genomics; ClinGen: Clinical Genome Resource; MMS: Microdeletion and microduplication syndrome; aCGH: Arraybased comparative genomic hybridization; TOP: Termination of pregnancy.
\end{abstract}

\section{Supplementary Information}

The online version contains supplementary material available at https://doi. org/10.1186/s12864-022-08340-y.

Additional file 1. Supplementary Table: The genomic positions, occurrences, genetic origins, and genetic modes of all $128 \mathrm{genes}$.

\section{Acknowledgements}

The authors are grateful to the patients and family members who participated in this research program.

\section{Authors' contributions}

LC and JW conceived and designed the study. LW, DY, FT, YZ, HZ performed the experiments. LC, JW and LW performed the bioinformatics analysis. LC wrote the manuscript, with contributions from LW, DY, FT, YZ and HZ. JW provided funding. All authors contributed to and approved the final version of the manuscript.

\section{Funding}

This study was funded by grants from the National Key R\&D Program of China (No. 2021YFC1005300 and 2021YFC1005302).

\section{Availability of data and materials}

The raw datasets used and analysed during the current study are not deposited in publicly available repositories because of considerations about the security of human genetic resources. The genetic mode and disease information of relevant genes in this article can be obtained from the OMIM database: https://www. omim.org/. For other details of the availability of data and material, please refer to the methods section of the article and Supplementary Table. Sequencing dataset can be obtained from the corresponding author on reasonable request.

\section{Declarations}

Ethics approval and consent to participate

The study was approved by the Medical Ethics Committee of West China Second University Hospital of Sichuan University (medical research 2016-7) and all experiments were performed in accordance with relevant guidelines and regulations. All pregnant women received genetic counseling and provided written informed consent as dictated by the Declaration of Helsinki.

\section{Consent for publication}

All pregnant women in this study agreed that their case data and test data were used for scientific research and public publication.

\section{Competing interests}

The authors declare no competing interests.

\section{Author details}

${ }^{1}$ Department of Obstetrics and Gynecology, West China Second University Hospital of Sichuan University, Chengdu 610041, China. ${ }^{2}$ Key Laboratory 
of Birth Defects and Related Diseases of Women and Children, Ministry of Education, Sichuan University, Chengdu 610041, China.

Received: 14 October 2021 Accepted: 28 January 2022

Published online: 02 February 2022

\section{References}

1. Dolk H, Loane M, Garne E. The prevalence of congenital anomalies in Europe. Adv Exp Med Biol. 2010;686:349-64.

2. Gergev G, Máté A, Zimmermann A, Rárosi F, Sztriha L. Spectrum of neurodevelopmental disabilities: a cohort study in hungary. J Child Neurol. 2015;30:344-56.

3. Kilby MD. The role of next-generation sequencing in the investigation of ultrasound-identified fetal structural anomalies. BJOG. 2021;128:420-9.

4. Fiorentino F, Napoletano S, Caiazzo F, Sessa M, Bono S, Spizzichino L, et al. Chromosomal microarray analysis as a first-line test in pregnancies with a priori low risk for the detection of submicroscopic chromosomal abnormalities. Eur J Hum Genet. 2013;21:725-30.

5. Xiao H, Yang YL, Zhang CY, Liao EJ, Zhao HR, Liao SX. Karyotype analysis with amniotic fluid in 12365 pregnant women with indications for genetic amniocentesis and strategies of prenatal diagnosis. J Obstet Gynaecol. 2016;36:293-6.

6. Wapner RJ, Martin CL, Levy B, Ballif BC, Eng CM, Zachary JM, et al. Chromosomal microarray versus karyotyping for prenatal diagnosis. $N$ Engl J Med. 2012:367:2175-84.

7. Levy B, Wapner R. Prenatal diagnosis by chromosomal microarray analysis. Fertil Steril. 2018;109:201-12.

8. Chau MHK, Cao Y, Kwok YKY, Chan S, Chan YM, Wang H, et al. Characteristics and mode of inheritance of pathogenic copy number variants in prenatal diagnosis. Am J Obstet Gynecol. 2019;221(493):e1-11.

9. Cohen K, Tzika A, Wood H, Berri S, Roberts P, Mason G, et al. Diagnosis of fetal submicroscopic chromosomal abnormalities in failed array CGH samples: copy number by sequencing as an alternative to microarrays for invasive fetal testing. Ultrasound Obstet Gynecol. 2015;45:394-401.

10. Chau MHK, Wang H, Lai Y, Zhang Y, Xu F, Tang Y, et al. Low-pass genome sequencing: a validated method in clinical cytogenetics. Hum Genet. 2020;139:1403-15.

11. Bartholmot C, Mousty E, Grosjean F, Petrov YKhau Van Kien P, et al. Apport de l'analyse chromosomique par puce à ADN dans un centre de diagnostic prénatal pluridisciplinaire [Contribution of chromosomal microarray analysis by a multidisciplinary prenatal diagnosis center]. Gynecol Obstet Fertil Senol. 2017;45:400-7.

12. Clinical Genetics Group Of Medical Genetics Branch Chinese Medical Association, Professional Committee For Prenatal Diagnosis Of Genetic Diseases Medical Genetics Branch Of Chinese Medical Association, Group Of Genetic Disease Prevention And Control Birth Defect Prevention And Control Committee Of Chinese Society Of Preventive Medicine. [Expert consensus on the application of low-depth whole genome sequencing in prenatal diagnosis]. Zhonghua Yi Xue Yi Chuan Xue Za Zhi. 2019:36:293-6.

13. Robson SC, Chitty LS, Morris S, Verhoef T, Ambler G, Wellesley DG, et al. Evaluation of Array Comparative genomic Hybridisation in prenatal diagnosis of fetal anomalies: a multicentre cohort study with cost analysis and assessment of patient, health professional and commissioner preferences for array comparative genomic hybridisation. Southampton (UK): NIHR Journals Library; 2017 Feb. PMID: 28182369.

14. Wang J, Chen L, Zhou C, Wang L, Xie H, Xiao Y, et al. Prospective chromosome analysis of 3429 amniocentesis samples in China using copy number variation sequencing. Am J Obstet Gynecol. 2018;219(287):e1-18.

15. Levy B, Stosic M. Traditional Prenatal Diagnosis: Past to Present. Methods Mol Biol. 2019;1885:3-22.

16. Callaway JL, Shaffer LG, Chitty LS, Rosenfeld JA, Crolla JA. The clinical utility of microarray technologies applied to prenatal cytogenetics in the presence of a normal conventional karyotype: a review of the literature. Prenat Diagn. 2013;33:1119-23.

17. Dong Z, Zhang J, Hu P, Chen H, Xu J, Tian Q, et al. Low-pass wholegenome sequencing in clinical cytogenetics: a validated approach. Genet Med. 2016;18:940-8.
18. Choy KW, Wang H, Shi M, Chen J, Yang Z, Zhang R, et al. Prenatal Diagnosis of Fetuses With Increased Nuchal Translucency by Genome Sequencing Analysis. Front Genet. 2019;10:761.

19. Yates CL, Monaghan KG, Copenheaver D, Retterer K, Scuffins J, Kucera CR, et al. Whole-exome sequencing on deceased fetuses with ultrasound anomalies: expanding our knowledge of genetic disease during fetal development. Genet Med. 2017;19:1171-8.

20. Richards S, Aziz N, Bale S, Bick D, Das S, Gastier-Foster J, et al. ACMG Laboratory Quality Assurance Committee. Standards and guidelines for the interpretation of sequence variants: a joint consensus recommendation of the American College of Medical Genetics and Genomics and the Association for Molecular Pathology. Genet Med. 2015;17:405-24.

21. AbouTayoun AN, Pesaran T, DiStefano MT, Oza A, Rehm HL, Biesecker LG, et al. ClinGen Sequence Variant Interpretation Working Group (ClinGen SVI). Recommendations for interpreting the loss of function PVS1 ACMG/ AMP variant criterion. Hum Mutat. 2018;39:1517-24.

22. Chang YF, Imam JS, Wilkinson MF. The nonsense-mediated decay RNA surveillance pathway. Annu Rev Biochem. 2007;76:51-74.

23. DiStefano MT, Hemphill SE, Cushman BJ, Bowser MJ, Hynes E, Grant AR, et al. Curating Clinically Relevant Transcripts for the Interpretation of Sequence Variants. J Mol Diagn. 2018;20:789-801.

24. Tumurkhuu M, Batbuyan U, Yuzawa S, Munkhsaikhan Y, Batmunkh G, Nishimura W. A novel BICD2 mutation of a patient with Spinal Muscular Atrophy Lower Extremity Predominant 2. Intractable Rare Dis Res. 2021;10:102-8.

25. Micheu MM, Rosca AM. Patient-specific induced pluripotent stem cells as "disease-in-a-dish" models for inherited cardiomyopathies and channelopathies - 15 years of research. World J Stem Cells. 2021;13:281-303.

26. Kohli U, Sriram CS, Nayak HM. A novel familial SCN5A exon 20 deletion is associated with a heterogeneous phenotype. J Electrocardiol. 2021:66:131-5.

27. Lek M, Karczewski KJ, Minikel EV, Samocha KE, Banks E, Fennell T, et al. Exome Aggregation Consortium. Analysis of protein-coding genetic variation in 60,706 humans. Nature. 2016;536:285-91.

28. Zukosky K, Meilleur K, Traynor BJ, Dastgir J, Medne L, Devoto M, et al. Association of a Novel ACTA1 Mutation With a Dominant Progressive Scapuloperoneal Myopathy in an Extended Family. JAMA Neurol. 2015;72:689-98.

29. Verhoeven K, De Jonghe P, Van de Putte T, Nelis E, Zwijsen A, Verpoorten $\mathrm{N}$, et al. Slowed conduction and thin myelination of peripheral nerves associated with mutant rho Guanine-nucleotide exchange factor 10. Am J Hum Genet. 2003;73:926-32.

30. Smadbeck JB, Johnson SH, Smoley SA, Gaitatzes A, Drucker TM, Zenka $\mathrm{RM}$, et al. Copy number variant analysis using genome-wide mate-pair sequencing. Genes Chromosomes Cancer. 2018;57:459-70.

31. Riggs ER, Andersen EF, Cherry AM, Kantarci S, Kearney H, Patel A, et al. Technical standards for the interpretation and reporting of constitutional copy-number variants: a joint consensus recommendation of the American College of Medical Genetics and Genomics (ACMG) and the Clinical Genome Resource (ClinGen). Genet Med. 2020;22:245-57.

\section{Publisher's Note}

Springer Nature remains neutral with regard to jurisdictional claims in published maps and institutional affiliations. 